\title{
Review of the Importance of Technology Company Valuation and Commonly Used Methods
}

\author{
Zhijiao Sun ${ }^{1, *}$ \\ ${ }^{1}$ Dalian Weide Integrated Circuit Co., Ltd, Dalian, Liaoning 116023, China \\ *Corresponding author. Email: sunjialu@victoric.com
}

\begin{abstract}
With the rapid development of technology companies around the world, the industrial system based on technology development now has more development space than ever before. Studying the development of new technology, as well as the value evaluation of technology firms, is essential for investing in technology-related industries. This paper analyzes existing problems when using each evaluation method for technology valuation. It can be concluded that absolute and market-based valuation is often not suitable for the valuation of technology companies. The qualitative methods that require inputs from industry experts are very subjective. The real option valuation method provides a more realistic (and greater) value of technology, since it allows managers to evaluate future development and upgrade value. When selecting the appropriate valuation model for technology company, it must be understood that the industry background in which the company operates and analyze the applicability of each method.
\end{abstract}

Keywords: Technology company, Methods, Valuation.

\section{INTRODUCTION}

With the rapid expansion of modern science, technology, and the economy since the 1990s, all types of technology businesses have exploded [1]. The valuation of technology and technology company is becoming increasingly essential, and it is used in intellectual rights trading, mergers and acquisitions, venture capital, securities market listing, and management decision-making, among other things. Intellectual property rights, human resources, and other intellectual resources have become strategic economic resources owned or controlled by enterprises in the context of the new economy, and can provide future excess economic benefits to enterprises; technology-based intellectual capital is becoming the primary determinant of future profitability [2].

Intangible assets are increasingly driven by corporation value and physical capital such as factories, machines and inventory, should be seen as a commodity available to all competitors and thus a marginal creator of value and competitive advantage [3]. This can be shown in the components of S\&P 500 market value (Figure 1), where intangible assets accounting for most of the company's market value. Technology, as an increasingly important intangible asset for companies, needs to be evaluated accordingly and conventional asset evaluation methods cannot justify the underlying value that technology innovation brings to the future of a company and new accounting methods needs to be explored. This study will first examine the characteristics of technology company and difficulties in technology valuation. Then this study will examine the relevance of various valuation techniques to evaluate technology company through comparison of advantages and shortcomings of each of the method to give a better overall picture of current valuation methods and provide guidance on the selection of valuation model. 


\section{COMPONENTS of S\&P 500 MARKET VALUE}

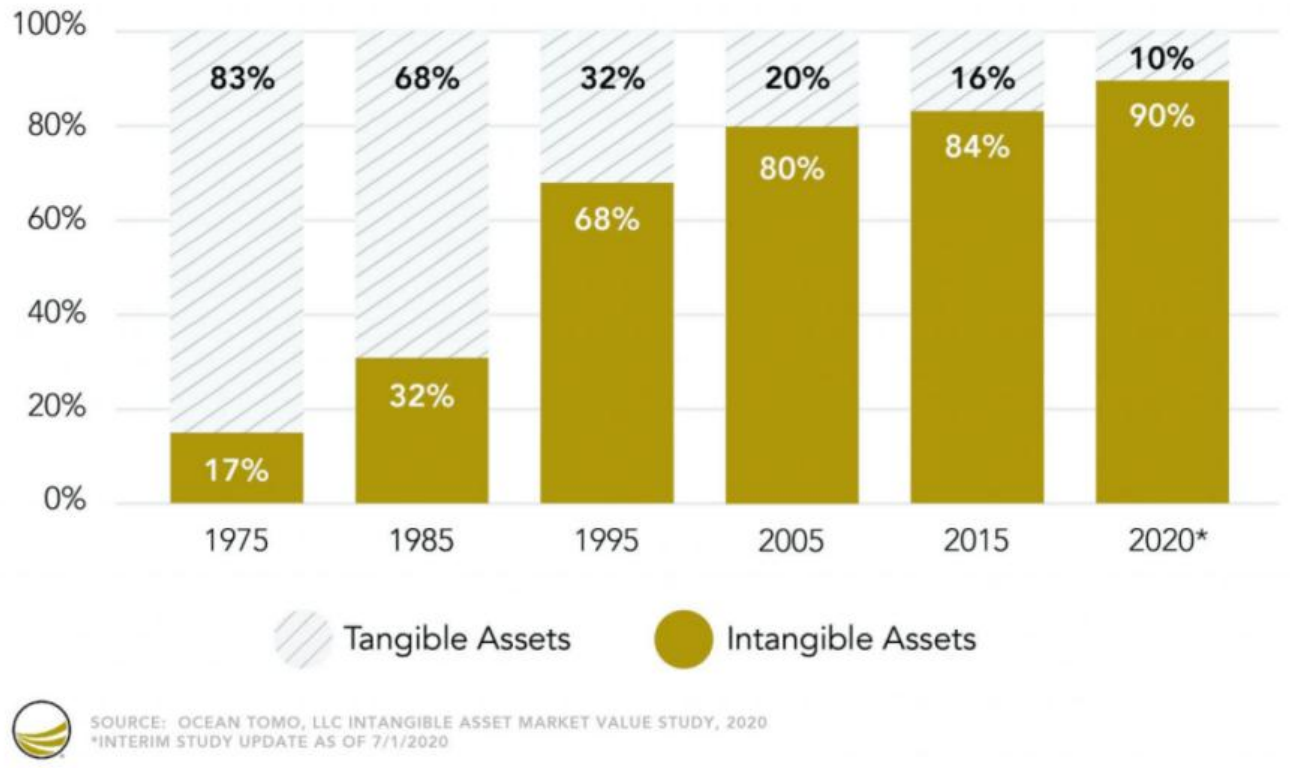

Figure 1 S\&P 500 companies market value in terms of tangible and intangible assets [4].

\section{ANALYSIS}

\subsection{Characteristics of Technology Companies}

Technology firms have distinct characteristics from traditional firms, such as high innovation, high investment, high risk, high return and high growth [5]. These firms typically have a high portion of intangible assets and technology innovation is critical for the firm's development. Because of these characteristics, high-tech firms' growth style, production, and management characteristics differ significantly from those of traditional firms, resulting in significant changes in the value composition of high-tech firms [1].

\subsection{High Research and Development Investment}

One of the main expenses in a technology company is the initial investment in research and development of new technology, and the weight of $\mathrm{R} \& \mathrm{D}$ funding is heavier in relative terms in the early stages of the company. Technology generated through this process is one of the company's most valuable assets and is critical to its future profitability and valuation and the initial costs for technology development are irreversible and should be considered as a sunk cost. For a technology to be profitable in the future, managers need to predict the demand of the market ahead of time.

\subsection{High Innovation}

Innovation is an ever-present theme in the evolution of times, and the creation of high-tech businesses is no exception. The proportion of new items and new technologies in sales volume is an important metric for identifying high-tech businesses. The quick development of high-tech businesses can be aided by innovation in technology, products, markets, and management. High-tech companies must do everything they can to increase their overall competitiveness by focusing on innovation. Ignoring or even preventing innovation is like planting a time bomb around it that will eventually be detonated by the market. Technological innovation is a major force for accelerating the growth of businesses. It is necessary to constantly boost the investment in technical innovation, in addition to protecting existing technologies. Institutional innovation is the only way for businesses to thrive, and they should be looking for new organizational structures and incentive mechanisms all the time. Because of their short life cycles, uncertain futures, tight timeliness, and rapid update speeds, high-tech products must constantly increase product innovation to fulfill changing market demands and achieve tremendous growth [6]. 


\subsection{High Growth Rate}

Technology is intangible, therefore could easily be replicated to support the company's rapid expansion. In fact, the value of technology companies has exploded in recent decades, and they frequently rank among the world's largest corporations.

\subsection{High-Profit Margin}

It is common for technology companies to achieve a very high gross profit over their products due to the relatively low cost of expansion of technology companies compared to traditional companies, and a high cost of entry for competitors due to the high cost of technology development and intellectual property protection laws.

It is these specific characteristics of technology companies which set them apart from companies within other industries and therefore making them difficult to value using traditional valuation methods, the next section shows some of the difficulties.

\section{DIFFICULTIES IN TECHNOLOGY COMPANY VALUATION}

\subsection{Large Portion of Intangible Assets}

Intangible assets make up a significant component of the assets of technology M\&A companies. Expertise, patents, and know-how are the most valuable assets of businesses, but their expenses are difficult to quantify. As a result, the presence of most intangible assets in technology M\&A firms has posed certain challenges in determining enterprise value [7].

\subsection{Lack of Historical Data}

Since the beginning of the twenty-first century, technology M\&A has gradually increased [7]; however, the market has not matured sufficiently, and there will be a lack of business information in the value evaluation, resulting in a lack of convincing basis in using past data to estimate the future value of enterprises, posing some challenges to technology evaluation.

\subsection{Uncertainty}

Technology firms are confronting more and more uncertainty in today's society, with increasingly strong technical rivalry, and this component of value has an increasing influence on technology firms, even more than the existing value of profitability. Technology companies bear enormous growth potential provided by future technological advancement, which is proportionate to the degree of uncertainty. Hence, they are relatively higher valued comparing to traditional companies due to this future potential growth. The difference of the value structure of technology enterprises also leads to the inadaptability of traditional enterprise value appraisal methods [1].

In fact, because high-tech businesses are involved in technology commercialization operations based on new scientific and technological breakthroughs, they are prone to development failure. And the extraordinary success of 20 percent to 30 percent of high-tech businesses comes at the expense of 70 percent to 80 percent of businesses failing. The collapse in the network valuation of the American Nasdaq market in April 2001 exemplifies this aspect. There is a lot of ambiguity about how such organizations will operate in the future, and future revenue growth could be exponential, which is impossible to predict using typical profit forecasting methods [6].

\section{TECHNOLOGY VALUATION METHODS}

\subsection{Absolute Valuation Methods}

Absolute valuation methods include the cost approach which measures the investment incurred for building the company; the discounted dividend method (DDM) which measures the present value of future dividends paid by the company and discounted cashflow method (DCF) which measures the future cashflow generated by the company's operations. 
Table 1. Summarizing Different Valuation Methods

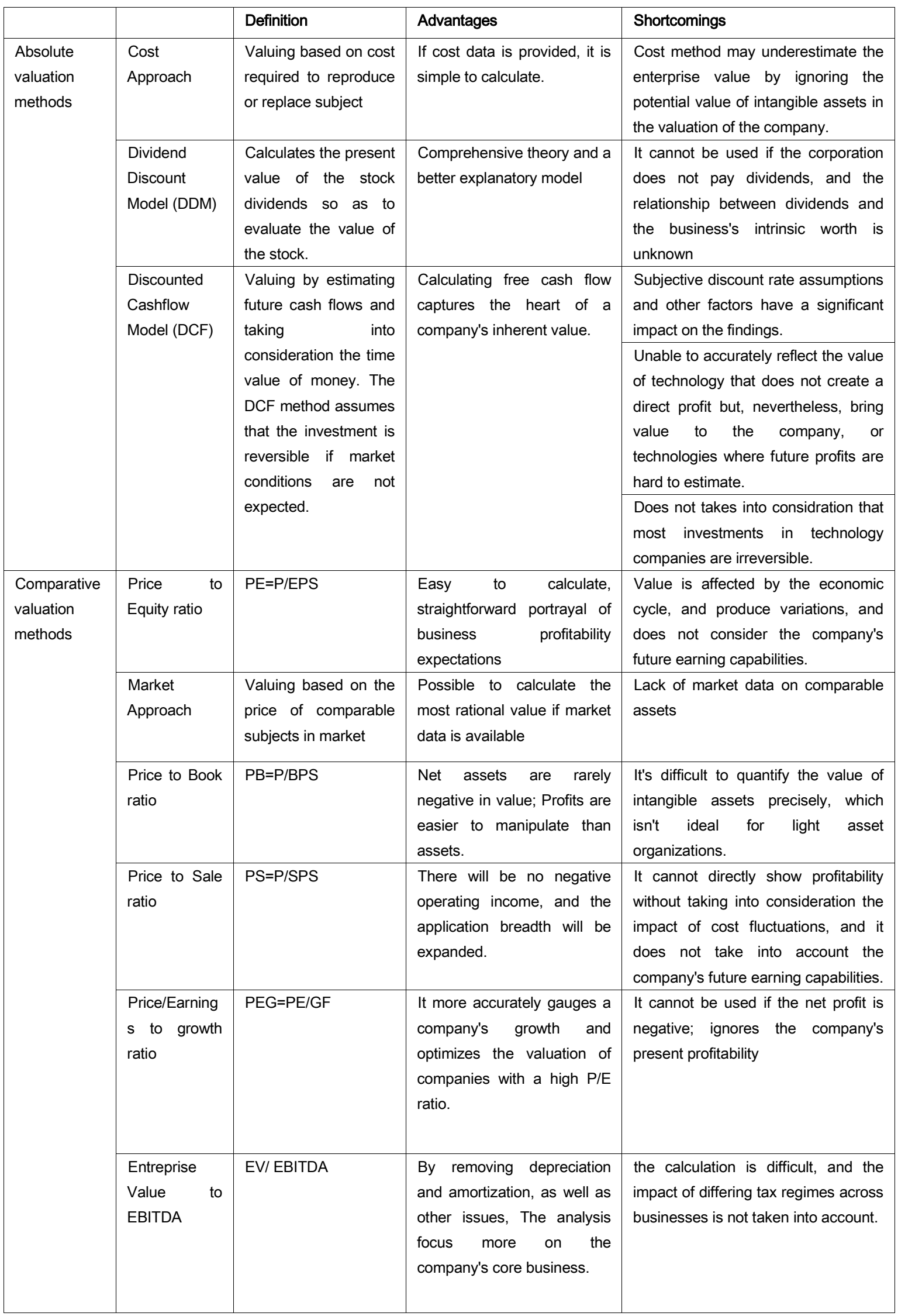




\begin{tabular}{|c|c|c|c|c|}
\hline & & Definition & Advantages & Shortcomings \\
\hline \multirow[t]{3}{*}{$\begin{array}{l}\text { Qualitative } \\
\text { valuation } \\
\text { methods }\end{array}$} & $\begin{array}{l}\text { Questionnaire } \\
\text { Interview with } \\
\text { domain } \\
\text { experts }\end{array}$ & \multirow{2}{*}{$\begin{array}{l}\text { Qualitative analysis } \\
\text { uses subjective } \\
\text { judgment to analyze a } \\
\text { company's value or } \\
\text { prospects based on } \\
\text { non-quantifiable } \\
\text { information, such as } \\
\text { management } \\
\text { expertise, industry } \\
\text { cycles, strength of } \\
\text { research and } \\
\text { development, and } \\
\text { labor relations. }\end{array}$} & $\begin{array}{l}\text { This method acquires } \\
\text { information directly from } \\
\text { domain experts who have } \\
\text { extensive experience in the } \\
\text { industry, therefore getting } \\
\text { more tailored assessment } \\
\text { within a specific industry. }\end{array}$ & $\begin{array}{l}\text { Subjective and unstable because the } \\
\text { result is dependent on the experience } \\
\text { and knowledge of domain experts. }\end{array}$ \\
\hline & $\begin{array}{l}\text { Quantification } \\
\text { of qualitative } \\
\text { factors }\end{array}$ & & $\begin{array}{l}\text { Rate qualitative factors of a } \\
\text { company using a numerical } \\
\text { scale and use this } \\
\text { information to calculate the } \\
\text { firms value. }\end{array}$ & $\begin{array}{l}\text { Subjective and unstable because the } \\
\text { result is dependent on the experience } \\
\text { and knowledge of the person } \\
\text { completing the evaluation. }\end{array}$ \\
\hline & & Definition & Advantages & Shortcomings \\
\hline \multirow[t]{2}{*}{$\begin{array}{l}\text { Real-option } \\
\text { valuation } \\
\text { method }\end{array}$} & $\begin{array}{l}\text { Black and } \\
\text { Scholes } \\
\text { Model }\end{array}$ & $\begin{array}{l}\text { Black-Scholes model } \\
\text { applies when the } \\
\text { limiting distribution is } \\
\text { the normal distribution } \\
\text { and it explicitly } \\
\text { assumes that the } \\
\text { price process is } \\
\text { continuous and that } \\
\text { there are no jumps in } \\
\text { asset prices. }\end{array}$ & \multirow{2}{*}{$\begin{array}{l}\text { The real option technique } \\
\text { depicts the value of } \\
\text { managerial flexibility and } \\
\text { indicates the underlying } \\
\text { profit potential of technology } \\
\text { businesses. In the real- } \\
\text { option valuation model, } \\
\text { investments are assumed to } \\
\text { be irreversible, which better } \\
\text { reflects the real-world } \\
\text { situation. Managers have the } \\
\text { ability to determine the best } \\
\text { time to invest, expand, } \\
\text { downsize or stop an } \\
\text { investment at different points } \\
\text { in time, depending on } \\
\text { changing situations. }\end{array}$} & \multirow[t]{2}{*}{$\begin{array}{l}\text { Real options pricing models are } \\
\text { either overly simplistic by making } \\
\text { unrealistic assumptions or too } \\
\text { complex to be applied in many } \\
\text { managerial settings, and the } \\
\text { variables have to be estimated } \\
\text { beyond personal bias which may be } \\
\text { not accurately. }\end{array}$} \\
\hline & $\begin{array}{l}\text { Binominal } \\
\text { model }\end{array}$ & $\begin{array}{l}\text { The binomial option } \\
\text { pricing model is based } \\
\text { upon a simple } \\
\text { formulation for the } \\
\text { asset price process, in } \\
\text { which the asset, in } \\
\text { any time period, can } \\
\text { move to one of two } \\
\text { possible prices. }\end{array}$ & & \\
\hline
\end{tabular}

The cost approach is not suitable to value technology company since the majority of technology M\&A enterprises operate in a light asset mode, with intangible assets accounting for a relatively high proportion of total assets. Because the value of intangible assets is largely reflected in the enterprise value, technology M\&A enterprises have a high option value, and the cost method may underestimate the enterprise value by ignoring the potential value of intangible assets.

The DDM method can only be used for publicly traded companies that regularly pay dividends, which is not the case for most technology companies. 
The DCF method can accurately value of foreseeable profitability of technology enterprises, but it does not reflect the value of their potential growth. An important assumption in DCF valuation method is the assumption that the investment is reversible. If the market conditions are not as good as expected, it is easy to withdraw and recover the initial investment. But in fact, especially in the investment of high-tech enterprises, when the enterprises give up a project, the initial investment will become sunk cost and cannot be recovered. The irreversibility of investment is a key feature of the existence of real options, which has been ignored by the traditional DCF method.

For technology enterprises with no profit history or are still losing money, it is impossible to calculate the profit growth rate based on the current profit when using DCF method. In addition, for young companies, the operation history of hightech enterprises is short, and the prediction and inference of future cash flow are not convincing.

An important characteristic of technology company is future uncertainty. To account for uncertainty, the DCF method usually reflects the investment risk brought by the uncertainty of future cash flow by adjusting the discount rate, which is subjective, making the DCF method not suitable for the valuation of technology companies.

\subsection{Comparative Valuation Methods}

Comparing to the DCF valuation method, comparative valuation method does not require accurate projections of the company's future, making them easier to use. These methods assume that the "fundamental" value of assets is less important than the market value, and unlike DCF, comparative methods use market-based data to perform the valuation. Comparative valuation uses less information on the firm and the cost of capital in general, lowering the expenses of preparation, and it automatically updates itself as market values change. However, the downside is comparative methods are based on current market information and do not take into account future profits and growth potential of a company.

Since technology is developed individually by enterprises through $\mathrm{R} \& \mathrm{D}$, they are unique and often cannot be compared against each other, making the use of comparative valuation methods obsolete.

\subsection{Qualitative Methods}

Some researchers have employed qualitative TV approaches such as questionnaire interviews with domain experts and quantification of qualitative factors for valuing technology companies. Because they relied on the experience and understanding of technological professionals, traditional TV approaches were subjective and unsteady [8]. Therefore, comprehensive but easily understandable methodologies are needed to solve the complicated problems resulting from the complexity of new technologies [9].

\subsection{Real Option Methods}

An option provides the holder with the right to buy or sell the underlying assets at a certain price in the future. The concept of real options was first put forward by American scholar Stewart Myers (1977). It refers to an enterprise's rights (not obligations) to carry out specific business activity in the future, such as the rights to delay, abandon, expand, convert, contract, and alter. It is a real and irreversible investment opportunity that exists. Real option method is the application of financial option in enterprise management, which provides another way of thinking for enterprise value evaluation [1].

Intangible assets such as patents and know-how are among the most valuable assets of technology companies, and they may provide investors with further earnings in the future. These intangible assets give a corporation the right to design and manufacture certain items. The corporation will only use this patent for manufacturing if the predicted cash flow from product sales exceeds the development cost. As a result, an enterprise's intangible assets can be viewed as call options, with created products serving as the underlying assets [10].

The real option technique captures the value of managerial flexibility, as well as the prospective profit opportunity value in technology businesses. Furthermore, the real option approach can evaluate an object with as few subjective factors as possible, allowing for a reasonable evaluation of the subject's value. As a result, when faced with high uncertainty, the real option technique can compensate for the shortcomings of DCF.

The binominal option pricing of the real option technique more explicitly depicts the options available for managerial decisions at different 
points in time than the Black Scholes model since it and the outcomes of the two models are similar [11].

\section{CONCLUSION}

As illustrated above, there are many different methods for company valuation. Technology companies have specific characteristics which set them apart from traditional businesses such as high initial $R \& D$ investment, high intangible asset value and high future growth potential. Therefore, selecting the appropriate valuation method is important and different factors need to be considered: First, absolute valuation methods such as the cost approach, DCF and DDM, requires stable projection of a company's future cashflow, which is often not the case for technology companies, and are not advised to be used for technology company valuation. Second, the industry in which the company exists, if it is a relatively grown industry, there will be comparable market information readily available and the valuation of the enterprise could be easily done using comparative methods. Third, qualitative methods are very subjective and its value dependent on the evaluator's subjective point of view, therefore should be carefully used and combined with other valuation methods to get more reliable result. Fourth, the real option valuation method provides a more realistic (and greater) value of technology since it allows managers to evaluate future development and upgrade value.

However, business decisions are extremely complex and interconnected and there is no perfect method for valuing technology companies. When selecting the appropriate valuation model for technology company, it must be understood that the industry background in which the company operates and analyze the applicability of each method.

\section{AUTHORS' CONTRIBUTIONS}

This paper is independently completed by Zhijiao Sun.

\section{ACKNOWLEDGMENTS}

I would like to express my gratitude to all those who helped me during the writing of this thesis. I acknowledge the help of Professor Colleen Honigsberg for her devoted teaching and enlightening lectures I have benefited in the preparation for the thesis. I would also like to thank professor Han Min and professor Bai Xue for reading through each draft and provide me with advices. This thesis could not reach its present form without their guidance.

\section{REFERENCES}

[1] Zhang Yanchun, Tan Jiabin. "The application of real option method in the value evaluation of high tech enterprises." mall modernization. 26 (2009): 24-25 doi:CNKI :SUN:SCXH.0.2009-26-016.

[2] Huang Xiaolin. Redefining Company Valuation: the value of technology [J]. Economic Observer, January 17, 2020

[3] Lev, B., Gu, F., (2016), "The End of Accounting and The Path Forward for Investors and Managers", Wiley, p. 82

[4] Ocean Tomo, LLC Intangible Asset Market Value Study, 2020

[5] $\mathrm{Xu}$ Yihua. Analysis of the impact of asset structure on profitability of high-tech listed companies [J]. Modern property (mid-month publication), 2013,12 (08): 52-54

[6] Fan Fengke, Sun Ruyan. "Research on the problems and methods of high-tech enterprise valuation." China asset valuation. 09 (2020): 24-27 doi:CNKI :SUN:ZCPG.0.2020-09-005.

[7] Sun Wenli, Liu Zixu. Value evaluation of technology merger and acquisition enterprises under real option method $[\mathrm{J}]$. Cooperative economy and technology, 2021 (11): 133-135

[8] Sunghae Jun, Sangsung Park \& Dongsik Jang (2015) A Technology Valuation Model Using Quantitative Patent Analysis: A Case Study of Technology Transfer in Big Data Marketing, Emerging Markets Finance and Trade, 51:5, 963-974,

DOI: 10.1080/1540496X.2015.1061387

[9] Lee, Y. and S. Lee. "The valuation of RFID investment using fuzzy real option." Expert Syst. Appl. 38 (2011): 12195-12201.

[10] Wang Yuxin, and Li Weizhuang. "Research on the evaluation of high-tech value based on real option theory." China asset appraisal.02 (2011): 19-22 doi:CNKI :SUN:ZCPG.0.201102-011.

[11] Rachmale, Adarsh. Applying Binomial Real Options to Technology Firm Valuation. Diss. 2020. 